3D model related to the publication: Marine Early Triassic Actinopterygii from Elko County (Nevada, USA): implications for the Smithian equatorial vertebrate eclipse

Romano, Carlo ; Jenks, James F ; Jattiot, Romain ; Scheyer, Torsten M ; Bylund, Kevin G ; Bucher, Hugo

DOI: https://doi.org/10.18563/m3.3.3.e1

Posted at the Zurich Open Repository and Archive, University of Zurich ZORA URL: https://doi.org/10.5167/uzh-139387

Journal Article

Published Version

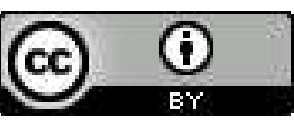

The following work is licensed under a Creative Commons: Attribution 4.0 International (CC BY 4.0) License.

Originally published at:

Romano, Carlo; Jenks, James F; Jattiot, Romain; Scheyer, Torsten M; Bylund, Kevin G; Bucher, Hugo (2017). 3D model related to the publication: Marine Early Triassic Actinopterygii from Elko County (Nevada, USA): implications for the Smithian equatorial vertebrate eclipse. MorphoMuseuM, 3(3):e1. DOI: https://doi.org/10.18563/m3.3.3.e1 


\title{
3D model related to the publication: Marine Early Triassic Actinopterygii from Elko County (Nevada, USA): implications for the Smithian equatorial vertebrate eclipse
}

\author{
Romano Carlo ${ }^{1 *}$, Jenks James F. ${ }^{2}$, Jattiot Romain ${ }^{1,3}$, Scheyer Torsten M. ${ }^{1}$, Bylund Kevin G. ${ }^{4}$, Bucher Hugo ${ }^{1}$ \\ ${ }_{1}^{1}$ Paläontologisches Institut und Museum, Universität Zürich, Karl Schmid-Strasse 4, 8006 Zürich, Switzerland. \\ 21134 Johnson Ridge Lane, West Jordan, Utah 84084, USA. \\ ${ }^{3}$ UMR CNRS 6282 Biogeosciences, Université de Bourgogne, 6 Boulevard Gabriel, 21000, Dijon, France. \\ ${ }^{4} 140$ South 700 East, Spanish Fork, Utah 84660, USA. \\ *Corresponding author: carlo.romano@pim.uzh.ch
}

\section{Abstract}

The presented dataset contains the 3D surface scan of the holotype of Birgeria americana, a partial skull described and depicted in: Romano, C., Jenks, J.F., Jattiot, R., Scheyer, T.M., Bylund, K.G. \& Bucher, H. 2017. Marine Early Triassic Actinopterygii from Elko County (Nevada, USA): implications for the Smithian equatorial vertebrate eclipse. Journal of Paleontology. https://doi.org/10.1017/jpa.2017.36

Keywords: Actinopterygii, Early Triassic, Nevada, Osteichthyes, Smithian

Submitted:2017-04-15, published online:2017-07-19. https://doi.org/10.18563/m3.3.3.e1

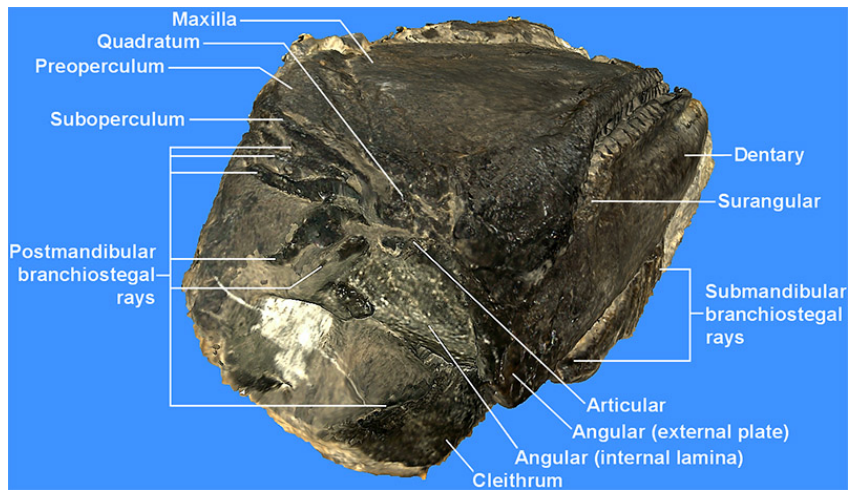

Figure 1. Holotype of Birgeria americana Romano et al., 2017 (NMMNH P-66225) from the Smithian (Olenekian, Early Triassic) of Winecup Ranch (Elko County, Nevada, USA) in oblique posteroventral aspect

\section{INTRODUCTION}

Here we present a 3D surface model of the holotype of Birgeria americana, an articulated partial skull, which was described by Romano et al. (2017). The fossil (NMMNH P66225; Fig.1) is preserved in a limestone concretion, and curated in the New Mexico Museum of Natural History \& Science, Albuquerque, USA. The nodule was found as float lying on strata of the Thaynes Group at a site located ca. 2.75 $\mathrm{km}$ south-southeast of the Winecup Ranch in east-central Elko County (northeastern Nevada, USA). Based on co-occurring ammonoids, the age of P-66225 is constrained to late early Smithian to early late Smithian (Olenekian, Early Triassic). Birgeria americana Romano et al., 2017 is distinguished from

$\begin{array}{ccl}\text { Model IDs } & \text { Taxon } & \text { Description } \\ \text { M3\#175_NMM } & \text { Birgeria } & \text { Articulated } \\ \text { NHP-66225 } & \text { americana } & \text { partial skull in } \\ & & \text { right view. }\end{array}$

Table 1. Associated model of NMMNH P-66225

other species by the presence of additional elements in the operculogular series, such as an antoperculum and six branchiostegal rays in the postmandibular series, including a rudimentary branchiostegal ray in the posteroventral part of the operculogular series. The species from Elko County is furthermore characterized by the presence of three discrete rows of teeth on the maxilla and dentary, whereas most other species have only two rows of teeth. The 3D surface model (Table 1) shows the arrangement and morphology of these diagnostic features.

\section{METHODS}

The 3D surface scan of NMMNH P-66225 (holotype of Birgeria americana Romano et al., 2017) was obtained using the ARTEC Spider 3D-surface scanner in combination with Artec Studio 9 software. The right side of the fossil was scanned manually in several steps and the overlapping individual scans were later stitched together to form a single mesh (including fine serial and global registration, automatic outliers removal and sharp fusion options). Then, the mesh simplification procedure of Artec Studio was applied to reduce file size. Finally, the color texture was mapped onto the mesh. The 3D surface model is provided in .ply and .obj format, and can therefore be opened with a wide range of freeware. 


\section{ACKNOWLEDGEMENTS}

This project was supported by the Swiss National Science Foundation grants 120311/135075 and 144462 (awarded to Winand Brinkmann, University of Zurich), 160055 (awarded to $\mathrm{HB}$ ), and 149506 (awarded to TMS).

\section{BIBLIOGRAPHY}

Romano, C., Jenks, J.F., Jattiot, R., Scheyer, T.M., Bylund, K.G. \& Bucher, H. 2017. Marine Early Triassic Actinopterygii from Elko County (Nevada, USA): implications for the Smithian equatorial vertebrate eclipse. Journal of Paleontology. https://doi.org/10.1017/jpa.2017.36 